TITLE PAGE

\title{
TITLE: Leprosy in a HIV infected patient
}

CORESPONDING AUTHOR: Clare M Galtrey

Address: Department of Neurology, St George's Hospital, Blackshaw Rd,London SW17 0QT

Telephone: 07764511193

Fax: 02087254591

Email: clare.galtrey@gmail.com

AUTHORS: Galtrey Clare $\mathrm{M}^{1}$, Modarres Hamid ${ }^{1}$, Jaunmuktane Zane ${ }^{2}$, Brandner Sebastian² Rossor Alexander $\mathrm{M}^{3}$, Lockwood Diana NJ4 ${ }^{4}$, Reilly Mary $\mathrm{M}^{3}$, Manji Hadi3, Schon Fred ${ }^{1}$

1. St George's University Hospitals, London, UK

2. Division of Neuropathology, Institute of Neurology, the National Hospital for Neurology and Neurosurgery, Queen Square, London, UK

3. MRC Centre for Neuromuscular Diseases, Department of Molecular Neurosciences, UCL Institute of Neurology, Queen Square, London, UK

4. London School of Hygiene \& Tropical Medicine, London, UK

KEYWORDS: Leprosy, HIV, Mononeuritis Multiplex

WORD COUNT: 1540 


\section{ABSTRACT}

A 60 year old Nigerian man, who had lived in Europe for 30 years but had returned home frequently, presented with weakness of the right frontalis and right ulnar nerve palsy with no skin lesions. Neurophysiology showed a generalised neuropathy with demyelinating features. Blood tests were positive for HIV with a normal CD4 count. Nerve thickening was subsequently demonstrated both clinically and on MRI. Nerve biopsy showed chronic endoneuritis and perineuritis (indicative of leprosy) with no mycobacteria seen. His neuropathy continued to deteriorate (lepra reaction) prior to starting treatment with WHO multi drug therapy, highly active antiretroviral therapy and steroids. Ten new cases of leprosy are diagnosed annually in the UK. Coinfection with HIV is rare but paradoxically does not usually adversely affect the outcome of leprosy or change treatment. However, permanent nerve damage in leprosy is common despite optimal therapy. Leprosy should be considered in patients from endemic areas who present with mononeuritis multiplex.

\section{KEY LEARNING POINTS}

1. Leprosy patients are regularly seen in the UK with about ten new cases a year and should be suspected in every patient with mononeuritis multiplex from an endemic area.

2. Pure neural leprosy (5\% of cases) can be difficult to diagnose due to lack of skin lesions and nerve biopsy is needed for diagnosis.

3. Deterioration before and after starting treatment (lepra reaction) is well recognised and patients require steroid treatment.

4. Even with modern treatments about $50 \%$ of patients will have major persistent nerve damage.

5. Paradoxically coinfection with HIV does not adversely affect the natural history of leprosy. 


\section{CASE}

A 60 year old right handed Nigerian man, with type 2 diabetes for 15 years, presented with right sided facial weakness. Direct questioning revealed 12 months of progressive numbness in arms, legs and face. On examination he had right sided facial weakness mainly affecting frontalis and a right sided ulnar nerve palsy. His biceps and supinator reflexes were present but triceps and lower limb reflexes were absent. His plantar response was mute. He had lived in Europe for over 30 years and returned to Nigeria several times a year.

He was found to be HIV positive with CD4 count 410 cells $/ \mathrm{mm}^{3}$, (normal $400-600$ cells $/ \mathrm{mm}^{3}$ ), CD8 count $158 \mathrm{cells} / \mathrm{mm}^{3}$ (normal $200-800 \mathrm{cells} / \mathrm{mm}^{3}$ ) and viral load 130,000 copies $/ \mathrm{mL}$ (normal 0 copies $/ \mathrm{mL}$ ). Syphilis serology was negative.

Cerebrospinal fluid examination was unremarkable with a white cell count of 1 cell $/ \mu \mathrm{L}$, protein $410 \mathrm{mg} / \mathrm{L}$ and paired oligoclonal bands in both serum and CSF, no atypical cells on cytology, no organisms in culture or on Gram stain and negative viral PCR.

He had neurophysiology studies (summarised in Table 1) which showed a rapidly progressive multifocal mixed sensory and motor neuropathy with evidence of demyelination and axonal loss. Motor conduction velocities were $29-40 \mathrm{~m} / \mathrm{s}$. All sensory nerve active potentials were absent. Blink reflexes confirmed bilateral facial nerve involvement with marked slowing of the R1 components bilaterally to 9 and $14 \mathrm{~ms}$ (normal $\geq 30 \mathrm{~ms}$ ).

Despite starting highly active antiretroviral therapy with Atripla (efavirenz, emtricitabine, and tenofovir) his neuropathy continued to deteriorate developing three months later bilateral hand weakness (Figure 1) and difficulty walking. Further examination revealed thickened peripheral nerves (bilateral ulnars, medians, right lateral popliteal and radial cutaneous nerves). There were no skin lesions. Repeat neurophysiology (Table 1) confirmed a new left ulnar palsy with more severe demyelinating features and secondary axonal changes. 1.5 Tesla MRI of limbs showed STIR hyperintensity and mild corresponding thickening and faint enhancement in T1w and post-contrast fat suppressed T1w of median, ulnar, radial, sciatic, tibial and common peroneal nerves.

The biopsy of the right ulnar nerve showed a severe chronic axonal neuropathy across the fascicles with a complete loss of myelinated fibres and better preservation of the unmyelinated fibres. The perineurium around one of the fascicles was concentrically thickened and fibrosed. There were infiltrates of histiocytes, $T$ and B lymphocytes and occasional plasma cells. Occasional perivascular mononuclear cells were also seen in the epineurium and endoneurium. There was no evidence of demyelination, no signs of active vasculitis and no granulomata. The tinctorial histochemical stain for the M.leprae acid fast bacilli was negative (Figure 2).

A clinical diagnosis of pure neural borderline tuberculoid leprosy with HIV coinfection was made on the basis of the grossly thickened nerves and the significant 
inflammatory changes on the nerve biopsy in a man from an endemic area for leprosy especially in the context of facial nerve involvement.

He was treated with World Health Organization leprosy multidrug therapy with rifampicin and dapsone. For six months, prednisolone was also given as standard treatment for tuberculoid leprosy neuropathy to prevent further lepra reaction related deterioration. His neuropathy remained stable with no further disability after six months and is followed up both by infectious disease and neurology.

\section{DISCUSSION}

The initial diagnosis was felt to be HIV related Chronic Inflammatory Demyelinating Polyneuropathy (CIDP) but facial palsies are extremely uncommon in CIDP and diabetic neuropathies. Common causes of thickened nerves are CIDP, multifocal acquired demyelinating sensory and motor neuropathy, leprosy, amyloidosis, neurolymphomatosis and Charcot Marie Tooth disease type 1 . The clinical combination of peripheral nerve thickening and facial nerve involvement strongly pointed towards leprosy (also known as Hansen's Disease) (Table 2).

Whilst bilateral symmetrical facial nerve palsies are common in Lyme disease, Sarcoidosis and Acute Inflammatory Demyelinating Polyradiculoneuropathy, the patchy and bilateral pattern of facial paralysis seen in this case is probably unique to leprosy. The branches are affected where they assume a superficial course, i.e.in the forehead over the zygomatic arch and the mandible as M.leprae grow at lower temperatures. The initial dysfunction is usually weakness of eye closure due to damage to the branches coursing over the zygoma and the orbital rim. Total facial paralysis is said not to occur even in advanced cases.

Leprosy patients are regularly seen in the UK.[1] Since it became a notifiable disease in 1951, there have been 1533 cases, approximately 10 per year. Most commonly patients originate from India, Sri Lanka, Pakistan and Nigeria. In endemic areas the diagnosis can be made clinically and classification on the number of skin lesions to allow treatment to be given without laboratory confirmation.

Confirmation of the diagnosis beyond clinical features is not always straightforward. The three cardinal signs are: hypopigmented or reddish skin lesion(s) with sensory deficit; peripheral nerve thickening and demonstration of acid fast bacilli in the lesions. The classic neurophysiological pattern seen in leprosy is a sensory-motor asymmetric multiple neuropathy with focal demyelination and distal axonal impairment. In paucibacillary leprosy, at diagnosis 10\% demyelinating (with 50\% axonal; $40 \%$ no conduction) and at follow up one year after stopping treatment $55 \%$ demyelinating (9\% axonal; 36\% no conduction).[2]

In non-endemic areas, such as the UK, it is usual to reach a conclusive diagnosis with either finding acid-fast bacilli (AFB) on microscopy (slit skin smears from skin lesions or ear lobes) in lepromatous cases or appropriate histological appearances 
(skin biopsy or in some cases, peripheral nerve biopsy) in tuberculoid cases as the effective immune response has eliminated the AFB.

This patient was unusual in having pure neural leprosy (about $5 \%$ of all cases) which lack skin lesions usually requiring nerve biopsy. M.leprae is only detected in $\sim 25 \%$ of tuberculoid case as the immune response has eliminated the bacteria leaving the inflammation of $M$. leprae DNA can be detected by PCR in $~ 50 \%$ of cases. Nerve neuropathology can aid the diagnosis with 4 categories: (i) confirmed with inflammatory infiltrates composed of AFB-loaded macrophages; (ii) highly probable with epithelioid granulomas in the absence of AFB; (iii) probable with inflammatory mononuclear cell infiltrate in nerve compartments, particularly endoneurium and perineurium (iv) possible with perineurial thickening and endoneurial fibrosis. In this case the nerve neuropathology was consistent with probable leprosy and AFB were not detected.

Patients with leprosy are classified on a clinical spectrum ranging from high cellmediated to high humoral immunity (Table 3 ). The cell-mediated response eliminates or contains the M.leprae in granulomas, while the ineffective humoral response allows the proliferation of mycobacteria. World Health Organization recommended treatment is with multidrug therapy according to disease classification: Multibacillary disease with Rifampicin 600 mg monthly, Dapsone 100 $\mathrm{mg}$ daily and Clofazimine $300 \mathrm{mg}$ monthly and $50 \mathrm{mg}$ daily for 12 months , paucibacillary disease with Rifampicin 600 mg monthly and Dapsone $100 \mathrm{mg}$ daily. Prednisolone is often added to multidrug therapy to reduce prevent nerve damage because without it $30 \%$ of people with borderline disease can deteriorate when multidrug therapy is started as a result of a reversal reaction. This occurs as the result of a sudden shift toward the cell mediated pole from the borderline state and can lead to irreversible nerve damage.

Recovery after treatment for leprosy neuropathy depends on the stage of disease at onset of treatment. In general, only $50 \%$ see functional improvement. Hence early diagnosis and treatment is important and long term rehabilitation strategies are necessary for many cases.

Perhaps surprisingly leprosy infection is only subtly affected by HIV coinfection.[3] HIV rates are high in leprosy endemic areas and although the number of co-infected patients is not known they are likely to be increasing. In contrast with the interaction with $M$. tuberculosis and disease due to Mycobacterium avium complex, M. leprae does not increase susceptibility to HIV. This paradox is not fully understood but may be due to differences in incubation times, the biology and toxicity of M.leprae compared to M. tuberculosis. As the clinical spectrum of leprosy depends on the host immunity (Table 3) and HIV principally affects host cell-mediated immune responses, it was predicted that co-infected patients would present with lepromatous disease but this is not the case. Co-infection with HIV does not alter the clinical features of leprosy. Leprosy in HIV-positive individuals is not shifted to the lepromatous pole nor does it develop more quickly. Response to treatment is unaffected.

Borderline disease comprises the intermediate spectrum of clinical forms of leprosy that are often immunologically unstable, potentially leading to reactional states. 
Some evidence suggests that the frequency and type of reactions are altered by HIV coinfection. Also, leprosy has been described as an immune reconstitution disease when HIV infection is treated with highly active antiretroviral therapy and the early rapid phase of immune reconstitution allows pre-existing infections to become clinically manifest or deteriorate typically as tuberculoid leprosy with type 1 leprosy reaction.

We present a case of mononeuritis multiplex in a known diabetic who was found to also have HIV infection, The final diagnosis was leprosy demonstrating the importance of considering leprosy if the patient has been in a prevalent area even when, as in this case, other explanations of a neuropathy are present. Also it is vital to consider the pattern of neuropathy present as the pattern of facial paralysis seen here is unique to leprosy. Considering leprosy and HIV co-infection provides further stimulus to examine the role of immune dysregulation in both infectious and immune mediated neuropathies.

\section{REFERENCES}

1. Lockwood DN, Reid AJ. The diagnosis of leprosy is delayed in the United Kingdom. QJM 2001;94:207-12.

2. Ooi WW, Srinivasan J. Leprosy and the peripheral nervous system: basic and clinical aspects. Muscle Nerve. 2004;30:393-409.

3. Lockwood DN, Lambert SM. Leprosy and HIV, where are we at? Lepr Rev. 2010;81:169-75.

\section{STATEMENTS}




\section{FIGURE LEGENDS}

\section{Figure 1: Clinical pictures}

Bilateral hand wasting

\section{Figure 2: Dorsal ulnar nerve biopsy}

Around some of the fascicles $(A)$ the perineurium (red arrow) shows marked concentric thickening and is infiltrated by inflammatory cells (the inset in A for a comparison shows thickness of the perineurium (green arrow) in a normal control nerve; the perineural thickness in the index and control fascicles is indicated with black lines). Mononuclear inflammatory cells with perivascular distribution are also present in the epineurium (blue arrow) and endoneurium (yellow arrow). Semi-thin resin preparation (B) shows a complete loss of myelinated fibres, whilst the axons (inset in B, immunostained for neurofilaments) highlights occasional remaining unmyelinated fibres. Immunotyping shows that the inflammatory infiltrate in the epineurium, perineurium and endoneurium is composed of a mixed population of CD68 positive macrophages (C) and CD3 positive T lymphocytes (D).

Scale bar: $200 \mu \mathrm{m}$ in $\mathrm{A}, \mathrm{C}$ and $\mathrm{D} ; 40 \mu \mathrm{m}$ in $\mathrm{B}$. 
Table 1: Neurophysiology

\begin{tabular}{|c|c|c|c|c|c|c|c|c|c|c|}
\hline \multicolumn{11}{|l|}{ SENSORY } \\
\hline SNAP-all & \multicolumn{10}{|l|}{ Absent } \\
\hline \multirow[t]{3}{*}{ MOTOR } & \multirow{2}{*}{\multicolumn{2}{|c|}{$\begin{array}{l}\text { Distal Latency } \\
\text { (ms) }\end{array}$}} & \multicolumn{4}{|c|}{ Amplitude (mV) } & \multirow{2}{*}{\multicolumn{2}{|c|}{$\begin{array}{l}\text { Velocity } \\
(\mathrm{m} / \mathrm{s})\end{array}$}} & \multirow{2}{*}{\multicolumn{2}{|c|}{$\begin{array}{l}\text { F response - } \\
\text { distal latency } \\
\text { (ms) }\end{array}$}} \\
\hline & & & \multicolumn{2}{|c|}{ Distal } & \multicolumn{2}{|c|}{ Proximal } & & & & \\
\hline & Mar & Dec & Mar & Dec & Mar & $D e c$ & Mar & Dec & Mar & Dec \\
\hline R. median & 5.8 & 8.3 & 6.0 & 0.20 & 3.0 & & 39 & & 31 & Absent \\
\hline L. median & 5.9 & 5.7 & 0.5 & 0.50 & 0.7 & 0.5 & 29 & 25 & & Absent \\
\hline R. ulnar & Absent & Absent & & & & & & & & \\
\hline L. ulnar & 3.5 & 6.9 & 11.0 & 0.50 & 7.0 & 0.4 & 40 & 19 & 32 & Absent \\
\hline $\begin{array}{l}\text { R. lateral } \\
\text { popliteal }\end{array}$ & 3.7 & 4.7 & 1.7 & 0.40 & 1.2 & 0.4 & 34 & 29 & 60 & Absent \\
\hline $\begin{array}{l}\text { L. lateral } \\
\text { popliteal }\end{array}$ & 5.0 & 4.0 & 8.0 & 3.30 & 5.0 & 2.5 & 39 & 37 & 59 & 55 \\
\hline $\begin{array}{l}\text { R. medial } \\
\text { popliteal }\end{array}$ & 6.8 & 7.3 & 1.4 & 0.04 & 1.4 & & 29 & & 67 & \\
\hline $\begin{array}{l}\text { L. medial } \\
\text { popliteal }\end{array}$ & 6.8 & 5.8 & 0.5 & 0.20 & & & & & 74 & Absent \\
\hline
\end{tabular}


Table 2: Differential diagnosis of patient presenting with features of leprosy

\begin{tabular}{|c|c|c|c|}
\hline & $\begin{array}{l}\text { Mononeuritis } \\
\text { multiplex }\end{array}$ & Bilateral facial palsy & Thickened nerves \\
\hline Traumatic & $\begin{array}{l}\text { Multiple compression } \\
\text { neuropathies }\end{array}$ & & \\
\hline Infective & $\begin{array}{l}\text { Hepatitis, } \\
\text { ParvovirusB19, Lyme, } \\
\text { Leprosy, HIV }\end{array}$ & $\begin{array}{l}\text { Lyme, Leprosy, HIV, } \\
\text { Tuberculous meningitis, } \\
\text { brainstem encephalitis, } \\
\text { syphilis }\end{array}$ & Leprosy \\
\hline Hereditary & $\begin{array}{l}\text { Hereditary neuropathy } \\
\text { with liability to pressure } \\
\text { palsies }\end{array}$ & & $\begin{array}{l}\text { Charcot Marie Tooth } \\
\text { disease type } \\
\text { 1,Refsum's disease }\end{array}$ \\
\hline Inflammatory & $\begin{array}{l}\text { Multifocal motor } \\
\text { neuropathy with } \\
\text { conduction block, } \\
\text { Multifocal acquired } \\
\text { demyelinating sensory } \\
\text { and motor neuropathy, } \\
\text { Vasculitis, Sarcoidosis, } \\
\text { Sjogren }\end{array}$ & $\begin{array}{l}\text { Acute Inflammatory } \\
\text { Demyelinating } \\
\text { Polyradiculoneuropathy, } \\
\text { Sarcoidosis }\end{array}$ & $\begin{array}{l}\text { Chronic Inflammatory } \\
\text { Demyelinating } \\
\text { Polyneuropathy, } \\
\text { MADSAM }\end{array}$ \\
\hline $\begin{array}{l}\text { CSF } \\
\text { disorders }\end{array}$ & & $\begin{array}{l}\text { Idiopathic intracranial } \\
\text { hypertension }\end{array}$ & \\
\hline Metabolic & Diabetes & Diabetes & \\
\hline Neoplastic & $\begin{array}{l}\text { Lymphoma, } \\
\text { Paraneoplastic }\end{array}$ & $\begin{array}{l}\text { Meningioma, } \\
\text { neurofibroma, malignant } \\
\text { meningitis }\end{array}$ & $\begin{array}{l}\text { Perineuroma, } \\
\text { Schwannoma, } \\
\text { neurofibroma }\end{array}$ \\
\hline $\begin{array}{l}\text { Nerve } \\
\text { infiltrations }\end{array}$ & Amyloidosis & & $\begin{array}{l}\text { Amyloidosis, } \\
\text { Neurolymphomatosis }\end{array}$ \\
\hline
\end{tabular}




\section{Table 3: Clinical spectrum of Leprosy}

Clinical presentation of leprosy reflects the cell-mediated immune response of the host. World Health Organization (WHO) classification defines either paucibacillary or multibacillary disease based on number of skin lesions. Ridley-Jopling classification creates a clinical spectrum of tuberculoid, borderline tuberculoid, borderline, borderline lepromatous, and lepromatous leprosy based on skin lesion type and bacterial load. Tuberculoid leprosy: vigorous cell-mediated immune response eliminates or contains the mycobacteria in granulomas resulting in well-demarcated lesions containing few bacilli and surrounded by lymphocytes. Lepromatous leprosy: no effective cell-mediated immunity allows the proliferation of mycobacteria within and around foamy macrophages. 


\begin{tabular}{|c|c|c|c|c|c|}
\hline WHO & $\begin{array}{l}\text { Paucibacilla } \\
\text { lesions) }\end{array}$ & (1-5 skin & Multibacill & y (>5 skin les & ons) \\
\hline Ridley-Jopling & Tuberculoid & $\begin{array}{l}\text { Borderline } \\
\text { tuberculoid }\end{array}$ & Borderline & $\begin{array}{l}\text { Borderline } \\
\text { lepromatous }\end{array}$ & Lepromatous \\
\hline $\begin{array}{l}\text { Cell mediated } \\
\text { immunity }\end{array}$ & \multicolumn{4}{|l|}{ High } & Low \\
\hline Type & $\begin{array}{l}\text { Polar } \\
\text { tuberculoid }\end{array}$ & \multicolumn{3}{|l|}{ Borderline } & $\begin{array}{l}\text { Polar } \\
\text { lepromatous }\end{array}$ \\
\hline Skin lesions & $\begin{array}{l}\text { Single/few } \\
\text { anaesthetic } \\
\text { patches;well } \\
\text { defined }\end{array}$ & \multicolumn{3}{|c|}{$\begin{array}{l}\text { Many anaesthetic lesions with indistinct } \\
\text { borders }\end{array}$} & $\begin{array}{l}\text { Multiple non- } \\
\text { anaesthetic } \\
\text { symmetric } \\
\text { patches }\end{array}$ \\
\hline Nerve lesions & $\begin{array}{l}\text { Asymmetric } \\
\text { al nerve } \\
\text { enlargement } \\
\text { proximal to } \\
\text { skin lesion }\end{array}$ & \multicolumn{3}{|c|}{$\begin{array}{l}\text { May produce most nerve damage and } \\
\text { multiple nerves involved }\end{array}$} & $\begin{array}{l}\text { No neural lesions } \\
\text { until late when } \\
\text { bilateral } \\
\text { symmetrical distal } \\
\text { neuropathy }\end{array}$ \\
\hline Histopathology & $\begin{array}{l}\text { Granulomas } \\
\text {; bacilli rare }\end{array}$ & \multicolumn{3}{|c|}{ Range; variable presence of bacilli } & $\begin{array}{l}\text { Foamy cells } \\
\text { numerous bacilli }\end{array}$ \\
\hline Stability & Stable & \multicolumn{3}{|c|}{$\begin{array}{l}\text { Unstable - may develop reactions and } \\
\text { new nerve damage }\end{array}$} & Stable \\
\hline
\end{tabular}

